\title{
An Approach to Understanding the Professionalism of Financial Planners
}

\author{
Ken Bruce, Abdullahi Ahmed and Helen Huntly \\ CQ University, Australia
}

\begin{abstract}
The aim of this research is to investigate how key stakeholder groups involved with the certification of financial planners experience the phenomenon of the 'professionalism of financial planners'. The study is to be carried out to provide insight to the international financial planning community in establishing relevant and superior professional standards for Certified Financial Planner (CFP) professionals. This will be a qualitative study using phenomenography as a research methodology to describe the qualitatively different ways in which certified financial planners, lecturers of the CFP curriculum and association managers understand or experience the phenomenon of 'professionalism'. Research participants will be interviewed from the United States, Australia and Hong Kong and these interviews analysed to reveal the variations in the conceptions of 'professionalism' and the attributes that can be identified from the phenomenographic outcome space to inform financial planners, academics and professional associations of what is required to be a CFP professional
\end{abstract}

\section{Keywords}

Ethics, financial planners, standards

\section{Introduction}

The objective of this research is to investigate how key stakeholder groups involved with the certification of financial planners globally under the Certified Financial Planner (CFP 1) brand, experience the phenomenon of the professionalism of financial planners. The aim of the study is to provide insight to the international financial planning community and in particular the CFP professionals, in establishing internationally relevant, superior professional standards for financial planners. This is a qualitative study at this stage which applies the phenomenographic research tradition that aims to describe qualitatively, the different ways in which people understand or experience a phenomenon.

\footnotetext{
* Corresponding author: CQUniversity Melbourne, 108 Lonsdale Street, Melbourne VIC 3000 Australia, Tel +61 38662 0582; E-mail address: k.bruce@mel.cqu.edu.au.

${ }^{1}$ The CFP designation is owned and controlled by the CFP Board of Standards in the United States and there are 24 member organizations of the Financial Planning Standards Board.
} 
The demand for financial planning services is growing. This demand can be explained by the growing middle class in developing countries such as China and India and also by the growing affluence of developed countries such as Australia and the United States. An increasing number of individuals are relying on the services of financial planners ${ }^{2}$ on an assumption that financial planners have attained an appropriate level of education, have appropriate level of technical knowledge and skills, and act in a professional manner. Against this back-drop, the financial services sector has struggled with an image problem, particularly as a result of the global financial crisis 2007-2010. In Australia, the collapses of Storm Financial and Opes Prime has eroded consumer and government confidence in financial product and service providers (Ripoll 2009).

The motivation for this research study is to identify the qualitatively limited number of ways in which financial planners, lecturers and association mangers understand the phenomenon of the professionalism of financial planners. This proposed study will limit investigation of the professionalism of financial planners to key stakeholder groups involved with the CFP brand. Whitfield's (2003) adaptation of Schwab's (1973) five bodies of experience has been adapted to identify three key stakeholder groups involved with financial planning as the research participants for this study.

The main research questions of this study are:

1. What are the conceptions of professionalism of the key stakeholder groups of CFP professionals, lecturers of the CFP curriculum and association managers?

2. What variations can be identified among these conceptions and;

3. What attributes of 'professionalism' from the revealed conceptions can be used to inform financial planners, academics and professional associations of what is required to be a professional financial planner?

\section{Background: historical perspectives of financial planning}

In order to understand how key stakeholder groups experience the professionalism of financial planners, it is necessary to understand the history of financial planning. An analysis of the historical development of financial planning will identify its path along a continuum towards how the occupation or profession is viewed today. Freidson (1986, pp. XIV-XV) captures the essence of this when he says, "both historical and contemporary studies are essential for a full understanding of the world, the one to follow the course of various streams of events flowing toward the present and the other to examine the contemporary pool into which all those separate streams flow".

Financial planning has a relatively short history with its origins dating back only to 1969 (Brandon Jr. \& Welch 2009). Although other writers such as Thompson (2002) suggest that financial planning had its roots in investment counselling, a term used to describe advice given to the blue-blooded clients of Boston and Manhattan advisers back in the 1920s. He cites congressional hearings in 1940 on legislation to regulate investment advisers to support his contention. In contrast accounting has a much longer history, dating back to at least 1494 with Pacioli's treatise on double-entry accounting (Godfrey 2006) and possibly much earlier. Other writers also track the beginnings of financial planning as a new profession from the same time period. Warschauer (2002) says personal financial planning commenced its evolution as a distinct field of endeavour from the 1970's and most probably from earlier beginnings. Eyssell (1999) says independent practitioners formed the heart of the new profession in the 1970's. They were independent because they provided advice not linked to any particular product. It would seem that from this humble

\footnotetext{
2 Individuals providing personal financial; planning services are also known as financial adviser. The term that is used in this thesis is financial planner as this is consistent with the scope of the study which focuses on understandings of financial planning as espoused by the CFP Board of Standards and the Financial Planning Standards Board.
} 
beginning, personal financial planning commenced its evolution into what now defines the occupation of financial planning.

Personal financial planning has evolved from a narrow field into a profession (Eyssell 1999). Pahl (1996) identifies the Chicago meeting as December 12, 1969 and that the purpose was to form two organizations The International Association for Financial Planning (as an industry association) and the College for Financial Planning (as the educational arm). The College for Financial Planning also registered the CFP and CFP designations as trademarks which licensed candidates to use the trademark (Pahl 1996). Brandon Jr. \& Welch (2009) also suggest that seeds of financial planning may have in fact commenced as early as the late 1940's with the writings of Joseph Schumpeter about 'creative destruction'. This was period of great economic excitement in the US - post-war - characterized by a radical innovation leading to a process of radical transformation. If you look at the chronology of events impacting on finance and markets in the US (Brandon Jr. \& Welch 2009), it might not be unreasonable to assert that financial planning had its beginnings in 1924 when mutual funds were introduced, or in 1933 when the Securities Act was passed.

The formation of the College of Financial Planning in 1972 was a critical event in the development of personal financial planning (Warschauer 2002) spawning many organizations such as the CFP Board of Standards Inc., the Financial Planning Association and the National Association of Personal Financial Advisors. Warschauer (2002) chronicles two important events as defining the "professional" era of the profession - the formation of the CFP Board of Standards in 1985, and the first job analysis study of CFP practitioners undertaken by the Board in 1987. Other designations followed with the Chartered Financial Consultant (ChFC) designation in 1982 by the American College followed by the American Institute of Certified Public Accountants Personal Financial Planning Division's Personal Financial Specialist (PFS) designation in 1986 (Pahl 1996). FPSB affiliates have largely adopted the US CFP Board's model of registering or accrediting education providers to deliver knowledge topic areas that prepare individuals for the CFP certification examination requirement. These knowledge topic areas essentially represent the body of knowledge of financial planning in the region of the FPSB affiliate member. The knowledge topic areas typically cover generic areas such as the process of financial planning and those characteristics of specialist knowledge areas that are generic in nature such as the principles of insurance, principles of investment or specific concepts such as risk and return, time value of money. The topics also mirror the practice of personal financial planning in the affiliate's own country. This related particularly to types and characteristics of financial products, legislation and regulation that may affect taxation considerations, estate planning and retirement planning strategies.

Gwen Fletcher, a leading Australian financial planning industry stalwart is attributed with bringing financial planning to Australia when she visited the United States in the early 1980's. Fletcher's discussions were about the creation and establishment of an affiliated chapter of the International Association of Financial Planning (IAFP) or a new industry body for Australia. The affiliation model was rejected by Department of Corporate Affairs, the regulatory body responsible at the time for issuing licenses to dealers of securities (Cowen et al. 2006). In 1982, the world convention of the IAFP was held in Australia with Gwen Fletcher as one of the organisers and from this meeting the Australian Investment Planner's Association (AIPA) was formed from primarily independent investment advisers. In 1984 after a group of Australians attended the annual American convention of the IAFP, IAFP (Australia) was formed (FPA Australia 2001). In the late 1980s, the AIPA was conscious that many practitioners held membership in both the AIPA and IAFP (Australia). The AIPA changed its name to the Australian Society of Investment \& Financial Advisers in an attempt to broaden its membership base. At the time IAFP (Australia) had the support of the banks and life insurance companies and in 1992, both bodies amalgamated to form the Australian FPA (Cowen et al. 2006).

The development of a professional set of competencies can be viewed as providing a benchmark of best practice, a resource for organizational evaluation, and as a framework for exploring relationships between practice, education and training (Birkett 1996). More specifically, Birkett (1996) indicated that competency is a relational notion in that individual attributes (knowledge, skills, attributes) are drawn on in performing tasks in a particular work context. Thus, competency is realized in performance, but relies on a capacity to display a set of skills including both technical and behavioural skills (Jackling \& Sullivan 2007). The Commonwealth Government introduced the Financial Services Reform Act (FSRA, 2001) aimed at 
regulating the situation where a client is unable to determine the competency of a financial intermediary because of lack of information or expertise. This regulation has had substantial implications for training in the financial services industry with amendments to the Corporations Act (2001) and particularly with the introduction of Policy Statement 146 (PS 146) ${ }^{3}$ (ASIC 2005 cited in Jackling \& Sullivan 2007).

The role of regulation and regulatory authorities in developing professions provides a contextual backdrop to the study. Regulators are very important in creating and guiding professional bodies and generating community trust. This is common for many professions, particularly the medical profession where governments play a role in protecting the public interest. Regulation is also important with financial services and specifically with respect to financial planning, where protection of the public is a key motivation for government. For the three countries that are the focus of this current study, examples of regulation aimed at ensuring that financial planners have appropriate competence can be seen through examination requirements. In the Unites States, the Financial Industry Regulatory Authority (FINRA) requires general securities representatives to sit a Series 7 exam; the Hong Kong Securities Institute (HKSI) also requires securities representatives to take an exam; and the Australian Securities and Investments Commission (ASIC) requires advisers to demonstrate competence by completing a training program listed on the ASIC Training Register as required by Regulatory Guide 146. ASIC has also released a discussion paper (CP 153), where among other measures it is recommending the introduction of a national exam for all current and new advisers with comments required by 1 June 2011.

\section{Literature review}

The focus of this proposed study is the professionalism of financial planners and a review of the literature reveals that very little is known about how key stakeholder groups experience the professionalism of financial planners. There is a substantial body of work on the professions and professionalism. Much of what is written about professions is from a sociological point of view, as studies of professions clearly indicate the interplay between the professions and society generally (Brante 1988). It is not the intent in this study to explore extensively the literature on the sociology of the professions and professionalism, but rather to provide context to identifying how key stakeholder groups experience the professionalism of financial planners. We are in a period where the traditional sociology of professions has been questioned and have moved into a period of post-professionalism and this is relevant to understanding the conceptions of professionalism.

Much has been researched and written on the professions, but few words have regularly experienced a shift in their meaning as have "profession" and "professional" (Watson 2002). These terms have different meanings if used in every-day use in society or if used in sociology. Watson (2002) also argues that 'professionalism', in certain usages, tends to be a vehicle used to further or defend a particular occupational interest. Authors have a tendency to write of occupations that have been successful in promoting themselves as a profession as if they were a profession, as opposed to being regarded as 'occupations' that have been successful in winning the respect attached to a profession (Watson 2002). Under the broadest possible definition of the term profession as used in society, carpenters, salesmen, and tailors would qualify as members of a profession, but it is apparent that they lack the philosophical direction that is commonly ascribed to a professional person (Roddenberry 1953).

According to O'Day (1986), historians were blinded to the importance of the growth of professions before the industrial revolution. A profession was defined as an occupation which exhibited certain traits including a collegial and hierarchical organization, group control of recruitment, entry qualifications and training, a self-imposed code of behaviour, and a claim to monopoly over the a defined body of knowledge and prac tical service (O'Day 1986). Furthermore, O'Day (1986) contends that although English awareness of the professions has a long history prior to 1800 , it is more from a genealogical perspectiv, e without true investigation of the functions performed within a profession. Evetts (2003) argues that it is possible to draw a distinction between professions and occupations. Professions are essentially the knowledge-based category of occupations which usually follow a period of tertiary education and vocational training and

\footnotetext{
${ }^{3}$ Now referred to as Regulatory Guide 146
} 
experience. Evetts (2003) also contends that maybe it is no longer so important to distinguish between professions and occupations but rather acknowledge them as similar social forms. Max Weber (1968) in his seminal work said much about the professions and the relationship between professionalization, bureaucratization and rationalization. He linked professionalization, to the rationalization of society. According to Ritzer, (1975) Weber linked professionals to the development of Western rationality, and to the development of a variety of specific institutions in the West. This was a two-sided relationship in that professionals contributed to rationalization of institutions and this process also developed professionals.

A study using secondary sources was carried out by Lee (1995), where he reviewed the nature of professionalization; the birth of the accountancy profession; the establishment and defence of professionalization; and a retrospect and prospect. The most obvious feature of early UK professionalization is the pursuit by accountants and their institutions of economic self-interest in the name of a public interest. Use of entry, examination and training requirements, lobbying over legislative matters, defending the exclusive use of professional designations and attempting statutory registration each illustrate this point. A similar pattern emerged in the USA in the late $1880 \mathrm{~s}$, although the specific rationale for professionalization was different from that of the Scots chartered accountants. For example, Walker (1988), and Kedslie (1990) point to the strengthening of the Scottish professionalization process by entry, education, examination and training requirements. Several writers (Brown 1905, Howitt 1966) identify a similar sequence of professionalization occurred in England, with the formation of local societies of accountants in the 1870s. However, unlike the Scottish formation, the English movement appears to have been little more than a series of imitating events as local accountants sought the credibility and authority of Scottish chartered accountants. According to Howitt (1966), the Institute proceeded quickly to impose standards of entry, examination and training, and was involved in influencing changes in law relating to accounting for bankruptcies and municipal auditing. Of particular concern were the Institute's requirement of an apprenticeship system, and the restricting of the activities of its members to those of public accountancy. In contrast, Society membership was UK-wide with regional organizations and members in both public and private sectors of the economy. An examination system was initiated, and specific professional designations were agreed. There also appears to have been a desire that the Society influence legislation affecting accountancy work (Garrett 1961). Lee (1996) examined the 1853 formation of the Institute of Accountants in Edinburgh (IAE), and its 1854 incorporation under charter as the Society of Accountants in Edinburgh (SAE) which he argues signalled the origins of sustained institutionalized professional accountancy, and therefore have considerable historical significance in helping to explain the professionalization process in public accountancy since the mid nineteenth century.

An understanding of profession and professionalism cannot ignore a post-professionalism perspective. Professions and the notion of professionalism are undergoing rapid change in a new global information age which necessitates new theories and explanations (Burns 2007). According to Kritzer (1999) postprofessionalism is characterised by loss of exclusivity, increased segmentation through specialization of knowledge and the growth of technology. As a result, the services previously delivered exclusively by members of formal professions can now be delivered by general professionals or even non-professionals (Kritzer 1999). An example of this is can be found with conveyancing clerks as para-legal professionals offering transfer of land services. Kritzer (Kritzer 1999) concludes that in this new post-professionalism world, professionals will remain central but that traditional professions will fade. "The new professionalism will be much more dynamic, reflecting the rapidity of change in the workplace and the accompanying demand in the market (Kritzer 1999, p. 749).

Professional associations play a role in socializing their members to the skills, competencies, and roles needed to perform effectively in bureaucratic organizations (Rusaw 1995). Horsley \& Thomas (2003) carried out a study to look at the exploration of unprofessional conduct procedures across the professions. The study was conducted to analyse (1) comparative information on how different professions structure, manage and organise procedures for accountability and professional misconduct; (2) the role of professional associations in the accountability process; (3) the role of government bodies' accreditation, registration and licensing as they relate to accountability. The researchers revealed that peer review played a pivotal role in the professional autonomy. Other writers such as Karseth and Nerland (2007) have argued that discourses of knowledge are employed by modern-day professional associations as a means of promoting professionalism. By analysing policy documents from the Norwegian associations for teachers, 
nurses, engineers and accountants, the authors revealed dominant knowledge discourses and argued how that these discourses serve to position the associations in distinct ways towards practitioners, working fields and the public community.

The hallmark of any profession is the presence of a common body of knowledge (CBOK) whose parts can be defined and defended (Lander \& Reinstein 1987). The first CBOK for accountants in the United States was produced in 1967 by Roy and MacNeil (Palmer et al. 2004). Given the realtively short history of financial planning, there is a dearth of literature about the financial planning CBOK. Ioannides (2005) asserted that as the common body of knowledge grows and planners continue to accept responsibility for their advice, financial planning will be recognized as a true profession. Overton (2008) claims that a theoretical body of knowledge for the Financial Planning Profession has always existed, until recently theory was not often explored as such, and there was no written common understanding or agreement on the theoretical basis of the financial planning profession. A CBOK can influence the training provided to those who are to become professionals in a chosen field (Roy \& MacNeill 1966). In Australia, that late Professor Bill Birkett developed a comprehensive competency framework for the major accounting bodies in the early 1990's, also contributing competency standards for the Financial Planning Association of Australia for financial planners in Australia and New Zealand (Birkett 1996).

The 1980s and 1990s witnessed a proliferation of studies of professionals, professions and processes of professionalization (Cooper \& Robson 2006). The theoretical engagement of the studies during this time moved considerably beyond earlier trait and functionalist approaches that seemed to be characterized by an uncritical acceptance of professionals' self accounts (Cooper \& Robson 2006). The authors argue that during this period, the actions of professionals and regulators are no longer rationalized by reference to public interest explanations but rather by the need for closure and so secure professional legitimacy and status within particular markets. A common position in the accounting literature is to examine the process of professionalization and accounting and audit regulation through the context of organizations such as standard setting bodies, regulatory agencies of government and supra-national regulatory bodies as if these institutions alone should be considered. (Cooper \& Robson 2006). Professional closure is often discussed in relation to education practices and struggles between the state and professional associations about regulations over practice rights and similarly, professional regulation is typically viewed as involving struggles over accounting and audit laws and standards (Cooper \& Robson 2006). This illustrates that the focus is on the relationship between professional bodies, standard setters and the government regulators. This situation mirrors what can be observed with financial planning. Financial planning is heavily controlled by the professional bodies such as CFP Board of Standards in the US, FPSB, FPA Australia and IFPHK.

A study undertaken by Jha et al (2006) investigated perceptions of professionalism in medicine. This was an interview study of medical educators, medical students, doctors, allied health professionals and lay professionals to assess views and experiences of professionalism in medicine. It involved thematic content analysis of the interview transcripts (Jha et al. 2006). The present study therefore is similar in that it offers an understanding of the professionalism of financial planners from different stakeholder perspectives. Instead of thematic content analysis, this present study will employ phenomenographic methods in attempting to understand the phenomenon of the professionalism of financial planners through an investigation of how financial planners, lecturers and professional association managers make meaning of professionalism from their own awareness (should be 'experience') of the phenomenon.

Very little is known about financial planning as a profession, the underlying theories of financial planning, nor the competence or professionalism of financial planners. A significant research study was undertaken in Australia (Smith 2009) however, that investigated professionalism and ethics in financial planning. This study focussed on the relationship between organisational environment and culture with the ethical decision making of financial planners. The findings of this study, among other things, identified patterns of unethical behaviour. The study proposed here is different from that of Smith (2009) in that it will take a second order perspective by understanding the phenomenon of professionalism through the eyes of those people closely involved in the CFP certification process. This research study will therefore be located in the current literature as contributing to the knowledge of 'profession', 'professionalism', and the professionalism of financial planners. A review of the literature on the closely allied profession of 
accounting provides a useful benchmark from which to understand historical perspectives of financial planning.

\section{Research Framework and Methodological Approach}

This research study will be unique in that the phenomenon will be investigated from the perspective of three major stakeholder groups who experience the phenomenon through their stake in the CFP certification process. ${ }^{4}$ Whitefield's (2003) adaption of Schwab's (1973) five bodies of experience has been used as a model to identify three key stakeholder groups of financial planners, lecturers and association managers for which conceptions of professionalism will be investigated.

In reviewing curriculum, Schwab (1973) describes five bodies of experience as the agents of translating knowledge into curriculum. These five bodies of experience constitute the subject matter in the form of scholarly materials, learners who are the beneficiaries of the curriculum operation, milieu which includes community references and the environment in which learning takes place, knowledge and the flexibility of teachers to learn new knowledge; and the process of curriculum making itself. Schwab (1973) argues that each of these bodies of experience must discover the experience of the other as a preliminary to the process of designing a defensible curriculum. Of the five bodies of experience, subject matter, learners, milieu and teachers are referred to by Schwab (1973, p.502) as 'commonplaces of equal rank'. Whitefield (2003) has adapted Schwab's bodies of experience framework in applying it to a study on determining how a Bachelor of Business Accounting degree facilitates the development of personal and interpersonal skills. In Whitefield's (2003) adaptation of Schwab's framework subject matter is represented by the curriculum pertaining to personal and interpersonal skills development, learners is represented by graduates of the Bachelor of Business Accounting degree, the milieu is represented by employers as being representative of numerous external influences, and teachers is represented by the lecturers who design, develop and teach the curriculum. This framework has been developed further by Whitefield (2003) to take account of the literature and the realities dealing with personal and interpersonal skills development. Professional associations, government and overseas influences have been added to the framework. Whitefield (2003) argues that the professional associations through their role of accrediting accounting and business programs influence the curriculum design process. Whitefield (2003) argues also that government and overseas influences also guide the curriculum design process.

Figure 1: Comparison between Schwab's (1973), Whitefield's (2003) and the framework adopted for this research study.

\begin{tabular}{|c|c|c|}
\hline $\begin{array}{c}\text { Schwab's five bodies of } \\
\text { knowledge }\end{array}$ & $\begin{array}{c}\text { Whitefield's adaptation of } \\
\text { Schwab's framework }\end{array}$ & $\begin{array}{c}\text { Framework for this proposed } \\
\text { study }\end{array}$ \\
\hline Curriculum revision & $\begin{array}{l}\text { Skills development for accounting } \\
\text { students }\end{array}$ & $\begin{array}{l}\text { Conceptions of the professionalism of } \\
\text { CFP professionals }\end{array}$ \\
\hline Subject matter & Curriculum & CFP curriculum \\
\hline Learners & Graduates & CFP Professionals \\
\hline Milieu & Employers & Association managers \\
\hline \multirow[t]{4}{*}{ Teachers } & Lecturers & Lecturers \\
\hline & Government & Regulation \\
\hline & Overseas influences & \\
\hline & Professional bodies & \\
\hline
\end{tabular}

Source: Developed by the authors

\footnotetext{
${ }^{4}$ A follow-up second phase of the research consisting of a broader sample and conducting audio-taped interviews will be done next year.
} 
Under Schwab's (1973) and Whitefield's (2003) constructs, financial planners are learners or students as the recipients of the CFP curriculum ${ }^{5}$; lecturers deliver the CFP curriculum to the students; and association managers provide the milieu as the gatekeepers to the profession in determining who meets entry requirements and who can maintain professional membership based on adherence to standards of ethical behaviour and practice standards (refer figure 1).

\subsection{Methodological approach}

The approach applied in this paper follows a recent study (Magub, 2006) which adopted a phenomenographic methodology to investigate the experiences of the phenomenon of using the internet for information sharing on IT projects. Magub (2006) identifies IT projects in Australia, UK and US as case studies from which research participants were sourced. The utterances of nineteen participants representing seven professional groups across the three countries were analysed into categories of description and outcome space. In this proposed study, CFP certification in Australia, Hong Kong and the United States will be presented as case studies from which research participants will be sourced. Fifteen CFP professionals, nine lecturers from the accredited education providers, and six association mangers will be interviewed individually in order to identify and describe the variation in how they experience the phenomenon of the professionalism of financial planners. Marton (1988) recommends a research group of between 15 and 30 participants to best achieve the aims of phenomenographic enquiry. Experiences from a large number of phenomenographic studies have shown that data from 20 informants is usually enough to discover all the different ways of understanding the phenomenon in question (Larsson and Holmström, 2007).

Figure 2 An illustration of the second order perspective used in phenomenography adapted from Edwards(2005) and Berglund (2002)

\section{The Subjects:}

Financial planners

\section{Lecturers}

Association managers

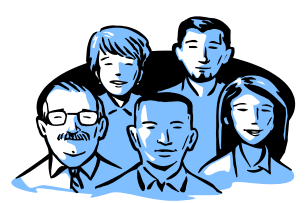

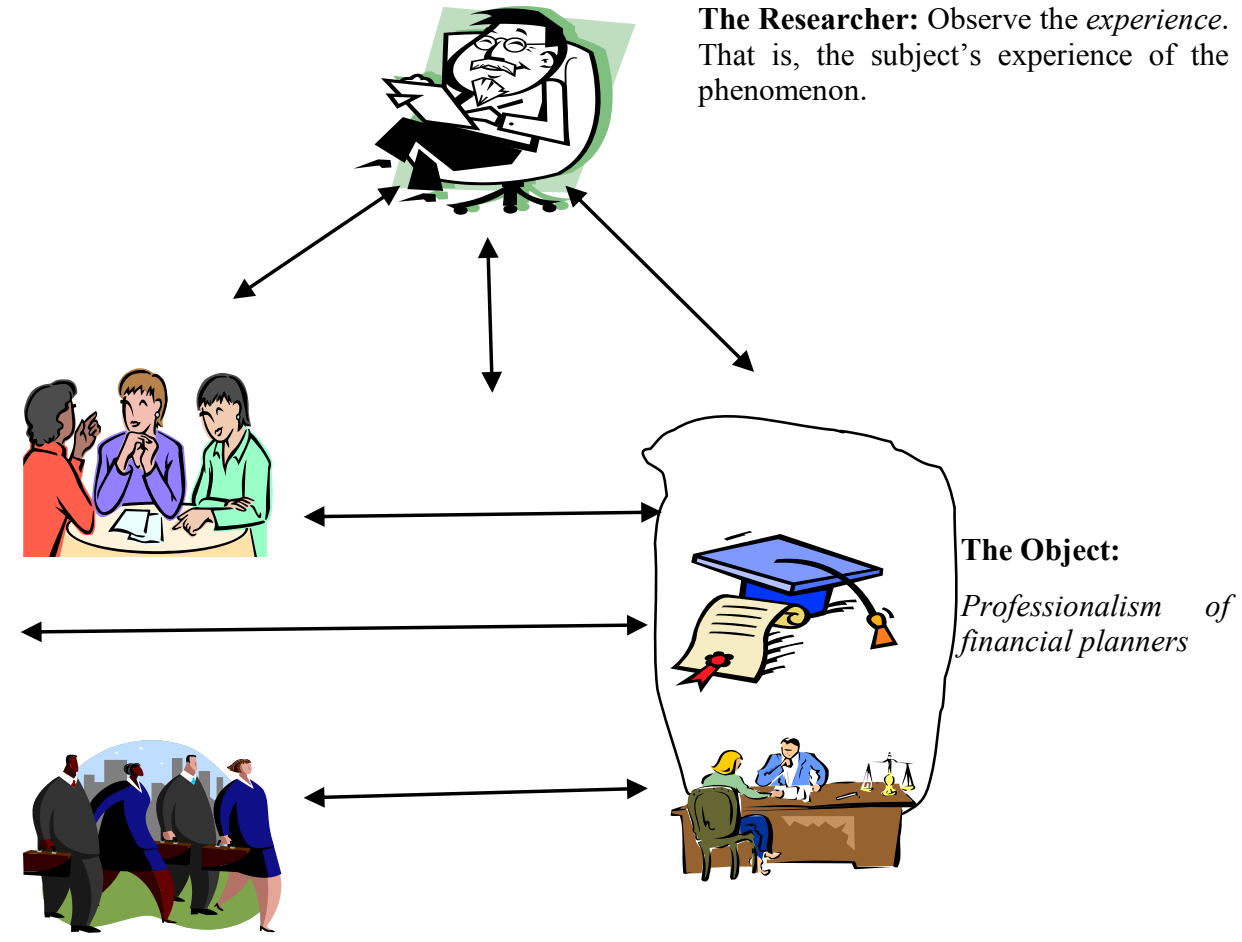

${ }^{5}$ CFP curriculum embraces entry level education requirements including registered/accredited CFP education courses, and on-going continuing professional development. 
Participants from the stakeholder groups will be interviewed in situ and the interviews will be audio-taped and transcribed verbatim. The interviews are loosely structured and open-ended around the primary question of "What does it mean to act with professionalism in the profession of financial planning?". This is to allow the researcher to explore the responses from participants in order to tease out the conceptions of the experience or awareness of the phenomenon. The interview transcripts will be analysed using iterative content analysis, where the utterances of the research participants are taken at face value and the researcher carries out a phenomenological reduction by delimiting his or her own understanding of the phenomenon (Uljens, 1996).

The study will identify a qualitatively limited number of ways the research participants experience the professionalism of financial planners. These will then be classified into categories of description and analysed to identify the hierarchical relationships between them as an outcome space which is anticipated to reflect an increased complexity of ways of experiencing the phenomenon and the logical inclusiveness of the categories. Phenomenography therefore takes a second order perspective (refer figure 2) with the researcher making statements about other peoples' experiences of the world, where the researcher attempts to see the world through the eyes of people experiencing it.

Conception is the unit of description in phenomenography (Marton and Pong, 2005) and therefore is the focus of the analysis. The literature reveals two frameworks that have been used by phenomenographers to analyse conceptions. The first framework distinguishing between the 'what' and 'how' aspects which are broken down to the 'act' itself, 'direct object' of the experience and the 'indirect object' of the experience (refer figure 3). The second framework distinguishes between structural and referential aspects of the experience which are further broken down into the internal and external horizons (Harris, 2011). Researchers such as Marton and Booth (1997) who have used the phenomenographic approach have variously used either framework or the two frameworks as one, as they are not mutually exclusive. This is highlighted in figure 4. An analysis of studies using phenomenography reveals differences in how these terms are defined and how they are used (Harris, 2011). For the purpose of this proposed study, the 'what' aspect of an experience is the direct object of experiencing the professionalism of financial planners; the 'how' aspect is the act of experiencing the phenomenon as well as an indirect object. The 'structural' aspect comprises an 'internal horizon' which consists of the aspects of the phenomenon which forms a theme of awareness, the relationships between these aspects and between the aspects and the phenomenon as a whole; and the 'external horizon' which consists of all aspects that are part of awareness.

Figure 3 The 'how' and 'what' aspects of the experience of the professionalism of financial planners adapted from Marton and Booth (1997, p. 85)

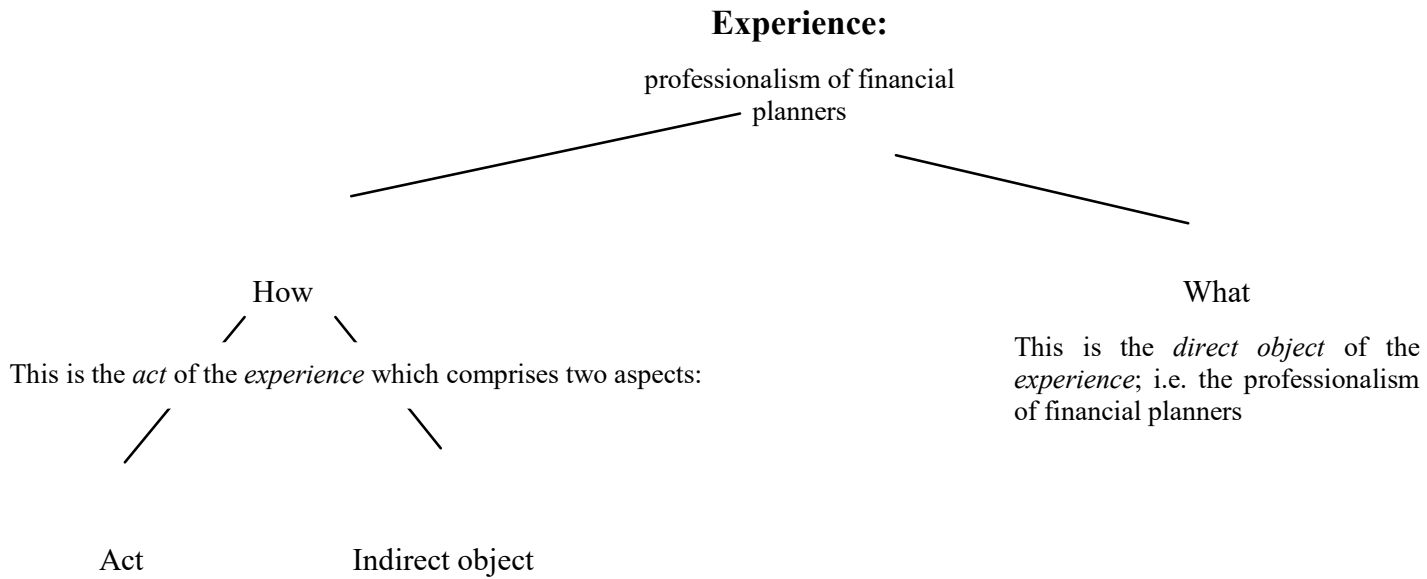


The 'referential' aspect is the intrinsic meaning attributed to the professionalism of financial planners. Therefore the internal horizon of the structural aspect of the how professionalism is experienced is the way in which the act of experiencing the professionalism of financial planners is carried out. For example an association manager might follow all the rules and procedures to certify an individual against the CFP mark. The internal horizon of the structural aspect of what is experienced about the professionalism of financial planners is the intention behind the act. For example for an association manager the intent might be to ensure that he/she is doing their job correctly or to protect the Professional Association from loss of reputation.

Figure 4 Aspects of the experience professionalism of financial planners adapted from Marton and Booth, (1997, p. 88 \& p. 91)

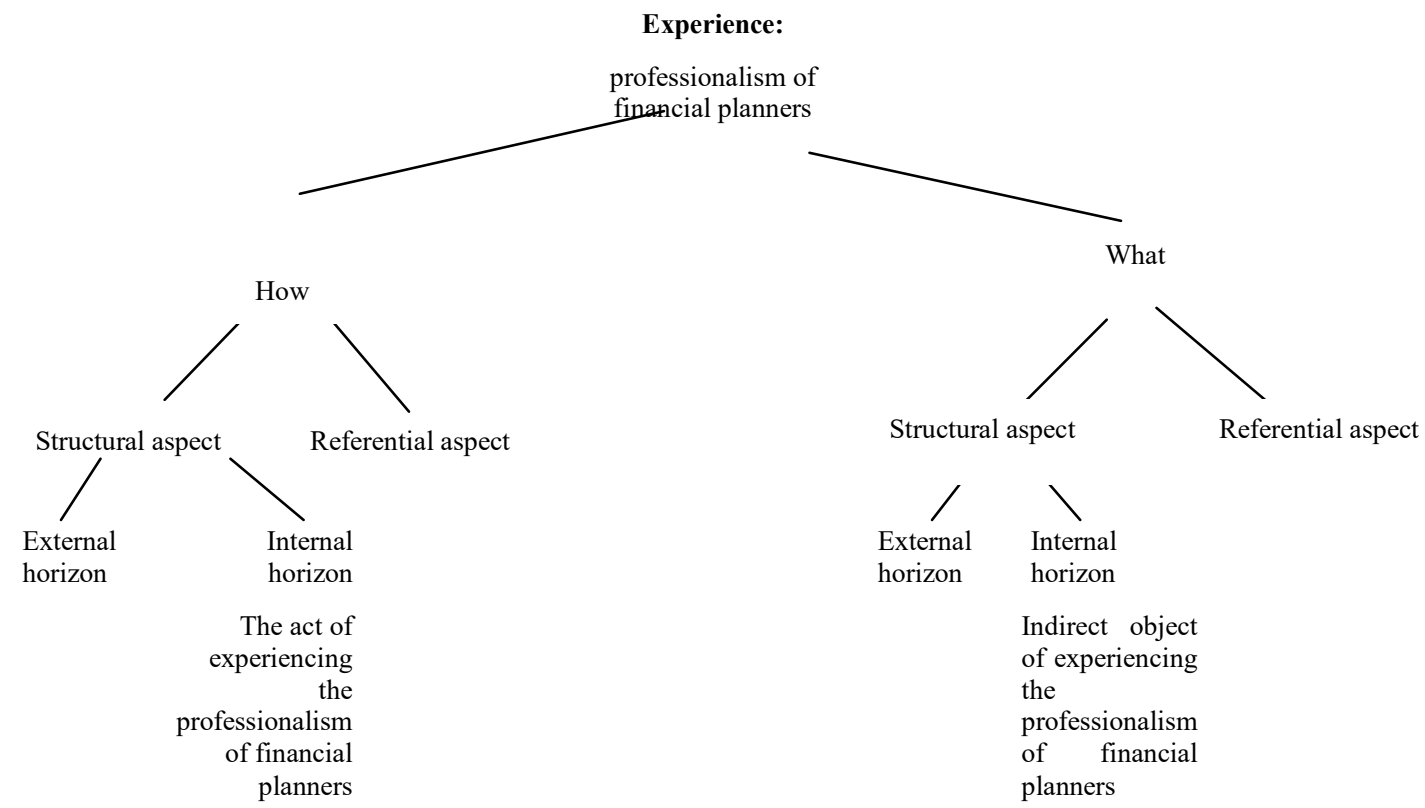

\section{Preliminary Findings and Some Policy Implications}

The field research comprising phenomenographic interviews in Australia, Hong Kong and the United States will be carried out in the second half of 2011. The global standard setting body for the CFP certification marks - Financial Planning Standards Board, as well as Financial Planning Association (US), Financial Planning Association (Australia) and the Institute of Financial Planners of Hong Kong have each expressed interest in the research and offered their assistance in sourcing interview participants. Preliminary discussions with these bodies have suggested a general lack of understanding of phenomenography as a qualitative research methodology that typically only involves small groups of research participants. As professional associations and standard setting bodies, these organisations frequently engage in quantitative research such as member satisfaction surveys and consumer sentiment surveys and are more comfortable with attributing numbers to research findings. This study presents a different approach that will contribute rich, descriptive data to the quantitative data already available 
Table 1: Comparison of education, examination, experience and ethics requirements

\begin{tabular}{|c|c|c|c|}
\hline & Australia & Hong Kong & United States \\
\hline Education & $\begin{array}{l}\text { Candidates complete } \\
\text { an approved } \\
\text { undergraduate or post } \\
\text { graduate course* as } \\
\text { entry to the CFP } \\
\text { Certification } \\
\text { Program** } \\
\text { **A Transcript } \\
\text { Review process is } \\
\text { available for } \\
\text { candidates who have } \\
\text { completed a finance- } \\
\text { related degree that has } \\
\text { not been approved by } \\
\text { the FPA. }\end{array}$ & $\begin{array}{l}\text { Candidates must } \\
\text { complete } \\
\text { comprehensive } \\
\text { education program } \\
\text { from one of the } \\
\text { approved education } \\
\text { providers of IFPHK. }\end{array}$ & $\begin{array}{l}\text { Candidates complete } \\
\text { an education } \\
\text { program registered } \\
\text { by the CFP Board of } \\
\text { Standards (includes } \\
\text { over } 300 \text { college and } \\
\text { university } \\
\text { programs). } \\
\text { Candidates can also } \\
\text { apply under a } \\
\text { Challenge Status if } \\
\text { they hold certain } \\
\text { credentials such as } \\
\text { CPA or CFA. } \\
\text { Candidates can also } \\
\text { request a Transcript } \\
\text { Review if they have } \\
\text { not completed a } \\
\text { registered education } \\
\text { program. }\end{array}$ \\
\hline Examination & $\begin{array}{l}\text { CFP }^{\circledR} \text { Certification } \\
\text { Assessment (CFP 5) } \\
\text { makes up the } \\
\text { examination part of } \\
\text { the CFP Certification } \\
\text { Program. r The } \\
\text { assessment verifies } \\
\text { that those wishing to } \\
\text { practice the } \\
\text { profession of financial } \\
\text { planning have } \\
\text { mastered a certain } \\
\text { level of theoretical } \\
\text { knowledge and } \\
\text { practical application } \\
\text { of that knowledge }\end{array}$ & $\begin{array}{l}\text { Candidates complete } \\
\text { the CFP } \\
\text { Certification } \\
\text { Examination } \\
\text { Candidates } \\
\text { required to pass four } \\
\text { (4) papers within five } \\
\text { (5) years (11 exam } \\
\text { intakes). }\end{array}$ & $\begin{array}{l}\text { Candidates must } \\
\text { complete a 10-hour } \\
\text { exam is divided into } \\
\text { three separate } \\
\text { sessions. All } \\
\text { questions are } \\
\text { multiple-choice, } \\
\text { including those } \\
\text { questions related to } \\
\text { case problems. }\end{array}$ \\
\hline Experience & $\begin{array}{l}\text { Three years of } \\
\text { financial planning } \\
\text { experience is } \\
\text { required. OR two (2) } \\
\text { years' experience in } \\
\text { the delivery of any } \\
\text { step in the financial } \\
\text { planning process to a } \\
\text { client, of which } \\
\text { twelve (12) months } \\
\text { experience in }\end{array}$ & $\begin{array}{l}\text { Three years full-time, } \\
\text { or the equivalent } \\
\text { part-time }(2,000 \\
\text { hours part-time } \\
\text { equals one year full- } \\
\text { time), if the } \\
\text { candidate has an } \\
\text { undergraduate degree } \\
\text { from a recognized } \\
\text { college or university. }\end{array}$ & $\begin{array}{l}\text { Three years full- } \\
\text { time, or the } \\
\text { equivalent part-time } \\
(2,000 \text { hours equals } \\
\text { one year full-time). } \\
\text { Six months of } \\
\text { experience must } \\
\text { have been gained } \\
\text { within } 12 \text { months of } \\
\text { reporting your work }\end{array}$ \\
\hline
\end{tabular}




\begin{tabular}{|c|c|c|c|}
\hline & $\begin{array}{l}\text { providing face-to-face } \\
\text { comprehensive } \\
\text { financial planning } \\
\text { advice. }\end{array}$ & $\begin{array}{lr}\text { Six years } & \text { full-time, } \\
\text { or the equivalent } \\
\text { part-time }\end{array}$ & $\begin{array}{l}\text { experience. } \\
\text { Experience may be } \\
\text { gained up to } 10 \\
\text { years before or up to } \\
\text { five years after the } \\
\text { exam date. }\end{array}$ \\
\hline Ethics & $\begin{array}{l}\text { Candidates must: } \\
\text { - disclose any } \\
\text { involvement in } \\
\text { any criminal, civil, } \\
\text { self-regulatory } \\
\text { organisation or } \\
\text { government } \\
\text { agency } \\
\text { investigation or } \\
\text { proceedings } \\
\text { - agree to adhere to } \\
\text { the FPA Code of } \\
\text { Professional } \\
\text { Practice which } \\
\text { includes the Code } \\
\text { of Ethics, Rules of } \\
\text { Professional } \\
\text { Conduct and } \\
\text { Practice } \\
\text { Standards; } \\
\text { - Undertake } \\
\text { ongoing } \\
\text { Continuing } \\
\text { Professional } \\
\text { Development } \\
\text { (CPD) }\end{array}$ & $\begin{array}{l}\text { All candidates for } \\
\text { CFP }^{\text {CM }} \text { Certification } \\
\text { must agree to abide } \\
\text { by the: } \\
\text { - The IFPHK's } \\
\text { Code of Ethics } \\
\underline{\text { and Professional }} \\
\text { Responsibility t } \\
\text { - IFPHK's Financial } \\
\underline{\text { Planning Practice }} \\
\text { Standards performs } \\
\text { IFPHK also perform } \\
\text { a background check } \\
\text { and each candidate } \\
\text { must disclose any } \\
\text { investigations or } \\
\text { legal proceedings } \\
\text { related to their } \\
\text { professional or } \\
\text { business conduct. }\end{array}$ & $\begin{array}{l}\text { Candidates must } \\
\text { agree to adhere to } \\
\text { CFP Board's } \\
\text { Standards of } \\
\frac{\text { Professional }}{\text { Conduct }- \text { including }} \\
\text { the Code of Ethics } \\
\text { and Professional } \\
\text { Responsibility, Rules } \\
\text { of Conduct, and } \\
\text { Financial Planning } \\
\text { Practice Standards - } \\
\text { and to acknowledge } \\
\text { CFP Board's right to } \\
\text { enforce them } \\
\text { through its } \\
\begin{array}{l}\text { Disciplinary Rules } \\
\text { and Procedures }\end{array}\end{array}$ \\
\hline
\end{tabular}

The CFP Board of Standards has what is commonly referred to as the 4 E's of education, examination, experience and ethics as requirements of their certification process. The FPSB prescribes similar requirements for those CFP candidates outside the United States. Candidates for CFP certification must master theoretical and practical financial planning knowledge by completing a comprehensive course of study and must pass a comprehensive CFP Certification Examination that assesses their ability to apply integrated financial planning knowledge to real world client situations. Candidates must also meet relevant work experience standards (one-year supervised experience or a minimum of three years of unsupervised practice experience) in the financial planning process prior to being awarded CFP certification and agree to abide by a strict Code of Ethics and Professional Responsibility that defines their ethical responsibilities to the public, clients and employers. Certified financial planner professionals must disclose any investigations or legal proceedings related to their professional or business conduct and agree to place the interest of clients first, act fairly, diligently and with integrity, and offer clients professional services that are objective and based on clients' needs. CFP professionals must disclose in writing to clients information about their sources of compensation 
and conflicts of interest; maintain technical competence and fulfil ethical obligations. Every two years, they must complete at least 30 hours of continuing professional development education to remain current with developments in the financial planning profession. In addition, CFP professionals must disclose any public, civil, criminal or disciplinary actions that may have been taken against them during the certification period. Table 2 provides a comparison of the how the e E's of education, examination, experience and ethics are applied in Australia, Hong Kong and the US.

The FPSB has embarked on a program of applying consistency across all of its 24 affiliate organisations. In 2007 a meeting of academics and practitioners from affiliate organisations was convened to discuss issues relating to building a global financial planning curriculum. This program has developed to now involve several work groups developing standards on various aspects including curriculum, assessment, and professional framework. This work has continued since 2007 with the FPSB producing a CFP competency framework, knowledge topic areas and other guidance statements for its affiliate members. Through my professional involvement and experience with FPA Australia in working with several affiliate organisations and identified many areas of difference covering cultural, different education systems and nomenclature and difference understanding of ethical practice. Do CFP professionals identify with their professional standing as being a CFP professional or do they identify with their employer? Smith (2009) found that financial planners in Australia were largely influenced by their employer (licensee) when her research identified the presence of unethical cultures within financial planning practices.

\section{Conclusion}

This preliminary research offers an innovative approach to the study of professionalism for a specific profession. Much of the existing research on the professions and professionalism has focussed on historical perspectives and on identifying the characteristics that distinguish a profession and a professional from a sociological viewpoint. This research paper has described the variations in how key stakeholder groups experience professionalism as it relates to CFP professionals. In this context stakeholders refer to those groups directly involved in the certification of financial planners to prescribed standards of the CFP designation. These include the lecturers of the CFP Curriculum from accredited education providers, association managers who act as gatekeepers to those who have access to the CFP designation, and the Certified Financial Planners themselves.

The conceptions of professionalism will highlight potential gaps or weaknesses in the application of standards currently prescribed by the Financial Planning Association of Australia, the Institute of Financial Planners of Hong Kong and by implication the Financial Planning Standards Board, and the CFP Board of Standards in the US. It is hoped that the findings will signal to these standard setting and accrediting bodies whether the current prescribed standards and expectations of CFP professionals is reflected in the conceptions of these requirements through variations in how the key stakeholder groups experience or have awareness of the professionalism of CFP professionals.

This research study will contribute significantly to the existing literature by applying uniquely the phenomenon approach to investigate the issues of financial professionalism from the perspective of three major stakeholder groups who experience the phenomenon through their stake in the CFP certification process. The significance of this study is that it will identify the elements of professionalism that key stakeholder groups experience as being part of the professionalism of financial planners. The findings will contribute to work being undertaken by the Financial Planning Standards Board and its affiliate member organizations representing 23 countries and regions around the world including Australia and Hong Kong. The findings will also assist the CFP Board of Standards and the Financial Planning Association in the United States in developing the profession of financial planning. This study will contribute to the literature on the application of phenomenography as a qualitative approach in understanding how groups experience a phenomenon. Finally, the study 
will contribute to the body of knowledge on professions and professionalism - particularly in understanding the profession of financial planning.

The results of the study have the potential to influence the way in which the FPSB and its affiliate members develop their CFP certification process. The study will reveal how the three stakeholder groups experience the phenomenon of financial planners' professionalism and could identify gaps or omissions in the current programs and process underpinning CFP certification. This could result in revision of the CFP curriculum to those areas identified as important or essential for the professionalism of financial planners and the emphasis placed on these areas in delivering the curriculum. The results of the study also have the potential to inform the professional practice standards and code of ethics that the professional associations mandate of its CFP professionals.

\section{References}

Berglund, A. 2002. On the understanding of computer network protocols. Uppsala, Uppsala University, Department of Computer Systems, Information Technology.

Edwards, S. L. 2005. Panning for gold: influencing the experience of web-based information searching. Unpublished PhD thesis, School of Information Systems, Faculty of Infromation Technology, Queensland University of Technology.

Harris, L. R. 2011. Phenomenographic perspectives on the structure of conceptions: The origins, purposes, strengths, and limitationsof the what/how and referential/structural frameworks. Educational Research Review, doi:10.1016/j.edurev.2011.01.002.

Larsson, J. \& Holmström, i. 2007. Phenomenographic or phenomenological analysis: does it matter? Examples from a study on anaesthesiologists' work. International Journal of Qualitative Studies on Health \& Well-Being, 2, 55-64.

Magub, A. 2006. Experiences of the phenomenon of Internet use for information sharing on construction projects and skills set identification for effective project participation. Doctor of Philosophy Thesis, Queensland University of Technology.

Marton, F. 1988. Describing and improving learning. In R. Schmech (Ed), New York, Plenum.

Marton, F. \& PONG, W. Y. 2005. On the unit of description in phenomenography. Higher Education Research \& Development, 24, 335-348.

Schwab, J. J. 1973. 'The Practical 3: Translation into Curriculum'. The School Review, 81, 4, pp 501522.

Uljens, M. 1996. On the philosophical foundation of phenomenography. In Gloria Dall'Alba \& Biörn Hasselgren (Eds.) "Reflections on Phenomenography - Toward a methodology?" Göteborg: Acta Universitatis Gothoburgensis, 1996, pp. 105-130 [forthcoming] [Online]. Available: http://www.ped.gu.se/biorn/phgraph/misc/constr/phlo.phgr.html [Accessed 17 November 2010].

Whitefield, D. 2003. Personal and Interpersonal Skills Development in an Accounting Degree: A case study of accounting education. Doctor of Philosophy Thesis, Swinburne University of Technology. 